\title{
Contents: London Review of Education 18(2)
}

\section{Special feature: Artificial intelligence and the human in education (Part 1)}

Digital literacies and children's personalized books: Locating the 'self'

Natalia Kucirkova and Margaret Mackey

Artificial intelligence in schools: Towards a democratic future Sandra Leaton Gray

Can artificial intelligence help predict a learner's needs? Lessons from predicting student satisfaction

Dimitris Parapadakis

Artificial intelligence and the technological turn of public education privatization: In defence of democratic education

Kenneth J. Saltman

New digital laboratories of experimental knowledge production: Artificial intelligence and education research

Ben Williamson

\section{General articles}

Balancing the demands of validity and reliability in practice: Case study of a changing system of primary science summative assessment

Sarah Earle

What level of support is required to enable secondary school teachers to effectively teach first aid? A randomized trial

Lucy Ellis, Ellen Gordon, Mark Forsyth, Alexander Ward and Emily Oliver

Adapting to a new learning environment: Mainland Chinese students studying in master's degree programmes in Hong Kong

Manhong Lai and Genshu Lu

Resistance, professional agency and the reform of education in England

Stephen M. Rayner and Helen M. Gunter

Creative Connections: The power of contemporary art to explore European citizenship

Mary Richardson, Fernando Hernández-Hernández, Mirja Hiltunen,

Anabela Moura, Marie Fulková, Fiona King and Fiona M. Collins

Education in an uncertain future: Two scenarios

John White

\section{Book reviews}

Social Equality in Education: France and England 1789-1939, by Ann Margaret Doyle

Vincent Carpentier

This is an Open Access article distributed under the terms of the Creative Commons Attribution Licence (CC-BY) $4.0 \mathrm{https}: / /$ creativecommons.org/licenses/by/4.0/, which permits unrestricted use, distribution and reproduction in any medium, provided the original author and source are credited. https://doi.org/10.14324/LRE.18.2.00. (e-ISSN: 1474-8479). https://www.uclpress.co.uk/pages/london-review-of-education 
System Leadership: Policy and practice in the English schools system, by Susan Cousin

Ron Glatter

Routledge Handbook of NGOs and International Relations, edited by Thomas Davies

Maria Savva

Politics, Managerialism, and University Governance: Lessons from Hong Kong under China's rule since 1997, by Wing-Wah Law

Paul Temple 